\title{
Agro-morphological characterization of Bambara nut accessions [Vigna subterranea (L) Verdcourt] from Burkina Faso
}

\author{
KAMBOU Diane Judicaëlle*1, 2, NANDKANGRE Hervé3, OUOBA Adjima4, KONATE Moussa N'Golo², \\ SAWADOGO Nerbéwendé1, OUEDRAOGO Mahama², SAWADOGO Mahamadou1 \\ 1 Université Joseph KI-ZERBO, UFR-SVT, Ecole Doctorale Sciences et Technologies, Laboratoire Biosciences, \\ Equipe Génétique et Amélioration des Plantes, 03 BP 7021 Ouagadougou 03, Burkina Faso \\ 2 Institut de l'Environnement et de Recherches Agricoles (INERA), Département de Productions Végétales, \\ Laboratoire de Génétique et de Biotechnologies Végétales, 04 BP 8645 Ouagadougou, Burkina Faso \\ ${ }^{3}$ Centre Universitaire Polytechnique de Tenkodogo, Université Ouaga II 12 BP 417 Ouagadougou 12, Burkina Faso \\ ${ }^{4}$ Centre Universitaire de Ziniaré, Université Joseph KI-ZERBO 03 BP 7021 Ouagadougou 03, Burkina Faso \\ *Corresponding Authors: Email: kamboudiane1@gmail.com, Telephone: +226 7122 92 96/ +226 76152755
}

Original submitted in on $3^{\text {rd }}$ June 2020. Published online at www.m.elewa.org/journals/ on 30th September 2020 https://doi.org/10.35759/JABs.153.1

\begin{abstract}
Objectives: The agro morphological diversity of Bambara nut remains poorly understood. In this study 90 Bambara nut accessions were assessed for phenotypic variability of agronomic and morphological traits. Methodology and results: A trial was conducted at Rollo (Bam province) on 90 accessions of Bambara nut of 3 agro ecological zones in Burkina Faso. Accessions were evaluated on 27 morphological characters. Result of qualitative traits analysis showed dominance of cream-coloured seeds, butterfly-grey eyes, and smooth yellowish-brown pods. The majority of quantitative traits were discriminant at $1 \%$. The completed PCA indicates that the first two axes expressed $55.60 \%$ of the total variability. The dendogram highlighted four groups of diversity.

Conclusion and application of results: The agro morphological characterization showed great variability within the accessions studied. The different associations between yield components and the clustering into classes could be exploited in breeding programs for improvement of Bambara nut productivity.
\end{abstract}

\section{RESUME}

Objectifs: La diversité agro morphologique du pois bambara reste mal connue. Dans cette étude, la variabilité phénotypique des caractères agronomiques et morphologiques de 90 accessions de pois bambara a été évaluées.

Méthodologie et résultats: Un essai a été conduit à Rollo (Province de Bam) sur 90 accessions de pois bambara issues de quatre zones agro-écologiques du Burkina Faso. Les accessions ont été évaluées sur 27 caractères morphologiques. Les résultats de l'analyse des caractères qualitatifs ont montré la dominance des graines de couleur crème, des yeux gris papillon et des gousses lisses brun jaunâtre. La majorité des Caractères quantitatifs étaient discriminants à 1\%. L'ACP indique que les deux premiers axes ont exprimé $55,60 \%$ de la variabilité totale. Le dendrogramme a mis en évidence quatre groupes de diversité. 
Conclusion et application des résultats: La caractérisation agro morphologique a montré une grande variabilité au sein des accessions étudiées. Les différentes associations entre les composantes du rendement et la subdivision en classes pourraient être exploités dans les programmes de sélection pour l'amélioration de la productivité du pois bambara.

Mots clés: Pois bambara, caractères morphologiques, variabilité

\section{INTRODUCTION}

Bambara nut [Vigna subterranea (L.) Verdc.] is a grain legume of papillionaceae family and originates from Africa precisely from north-eastern Nigeria and northern Cameroon (Heller et al., 1997). Bambara nut is an important legume in Burkina Faso where it is ranked second after cowpea economically (Ouédraogo et al., 2008). It can be used by local population as food and in medicine for diseases treatment (Brink et al, 2006). Bambara nut seeds are rich in many components such as protein, carbohydrate (FAO, 2016) and have high antioxidant activity (Mbaiogaou et al., 2013). The plant is able to adapt to poorly watered and not very fertile soils thanks to drought tolerance and its capacity to fix atmospheric nitrogen (Gueye, 1989). In Burkina Faso, Bambara nut has an economical importance for the producers and the traders as cash crop and generate substantial incomes for households (NADEMBEGA, 2016). Despite its great

\section{MATERIAL AND METHODS}

Plant material: 90 Bambara nut accessions were used in this study. They have been collected from Burkina Faso's agro ecological zones: 18 accessions from sahelian zone, 17 from sudanian zone, 49 from sudansahelian zone and 6 from National Institute for the Environment and Agricultural Research (INERA) gene bank (Table 1).

Experimental site: The trials were set up on July 2018 in Rollo's located in the North Central Region of Burkina potentialities, there are not many studies on Bambara nut. Previous studies undertake were focused essentially on the farming system, notably on the effect of mounding time and influences of mineral and organic fertilizers on yield (Ouédraogo et al., 2012) but few works done by Ouédraogo et al., 2008 were interested on the agro morphological variability description. Characterization using morphological and agronomical trait is essential and constitute the first step in the knowledge of diversity within a population. In addition, knowledge of intraspecific variability of a plant in genetic resources conservation and utilization process is essential for establishment of future breeding program. This study has been carried out to contribute to better knowledge of Bambara nut through agro morphological characterization of 90 accessions from Burkina Faso.

Faso. Choice of the site is based on soils texture (sandblast) adapted to the cultivation of the Bambara nut. Climate of Rollo's site is Sudan-Sahelian characterized by a rainy season (from June to October) and a dry season (from November to May). Rainfall varies between 400 and $600 \mathrm{~mm}$ per year with an average of 33 days of rainfall per year and average temperatures between $28^{\circ} \mathrm{C}$ and $29^{\circ} \mathrm{C}$ (PCD, 2015) 
Kambou et al., J. Appl. Biosci. 2020 Agro-morphological characterization of Bambara nut accessions [Vigna subterranea (L) Verdcourt] from Burkina Faso

Table 1: Bambara nut accessions used and their location

\begin{tabular}{ll}
\hline Origin & \multicolumn{1}{c}{ Accessions } \\
\hline INERA & KVS 235, KVS 235 100 GY, KVS 246-1, KVS 246-2, KVS 246-3, Life 16-141 \\
\hline \multirow{2}{*}{ Sahelian } & E 105b, E 108, E 110a, E 110b, E 111a, E 114, E 117, E 118, E 119, E 12, E 124a, E 124b, \\
& E 124c, E 125, E 126, E 13, E 59, E 61a \\
\hline \multirow{3}{*}{ Sudano sahelian } & E 01, E 03, E 04, E 09, E 103a, E 103b, E 105a, E 107, E 111b, E 131, E 132, E 16a, E 48, \\
& E 72, E 75, Nob-Loc, E 76a, E 76b, E 78a, E 83a, E 83b, E 88b, E 89a, E 89b, E90, E 92, \\
& E 93b, E 94, E 95a, E 95b, E 97, E 98, ED8, KAYA 2014 \\
\hline \multirow{2}{*}{ Sudanian } & E 101b, E 123, E 130, E 16b, E 20, E 22, E 23, E 25, E 26, E 27, E 28, E 44, E 76c, E 78b, \\
& E 83c, E 86, E 88a \\
\hline
\end{tabular}

Experimental setup: The experimental design used was a Completely Randomized Blocks with four replications. Each Bambara nut accession was sowed in $2.4 \mathrm{~m}^{2}$ plot area spacing with $40 \mathrm{~cm} \times 20 \mathrm{~cm}$ between lines and plants respectively. In each plot forty four seeds were sowed. The spacing between plots was 80 $\mathrm{cm}$ and $1 \mathrm{~m}$ between blocks. Recommended rate of 75 kg.ha-1 of NPK (23-14-23) fertilizer was used after sowing by spreading. Mounding was done at 7 weeks after sowing. Weeding was made regularly as need.

Data collection and analysis: Twenty-seven traits, constituted of 6 qualitative and 21 quantitative (Table 2) were observed during different stage of development and after harvest in accordance with Bambara nut descriptor established by the International Plant Genetic Resources Institute (IPGRI et Bamnet, 2000). Data analysis were carried out with the average values obtained by plot and by block for each accession. An analysis of variance (ANOVA) with two criteria of classification was made with Genstat software Version 2012. The study of the relations between the characters was made from the correlation matrix of Pearson and the accessions were submitted to the Principal Component Analysis (PCA) using XLSTAT version 2016. The well-represented characters were used to perform Agglomerative Hierarchical Clustering (AHC) of accessions based on Euclidean distance between individuals. 
Table 2: Qualitative and quantitative traits recorded and their codes

\begin{tabular}{|c|c|c|c|}
\hline Characters & Variables & Code & Notation \\
\hline \multirow{6}{*}{ Qualitative } & Terminal leaflet Form & TLF & - \\
\hline & Pod colour & PDC & - \\
\hline & Pod texture & PDT & - \\
\hline & Seed Colour & SEC & - \\
\hline & Presence of eye & POE & - \\
\hline & Colour and appearance of eye & CAE & - \\
\hline \multirow{21}{*}{ Quantitative } & Days to emergence & DTE & Day \\
\hline & Emergence at twenty-one days after sowing & ETO & Number \\
\hline & Days to first flowering & FFL & Day \\
\hline & Days to $50 \%$ flowering & HFL & Day \\
\hline & Number of leaves per plant & NLP & Number \\
\hline & Plant height & PHT & $\mathrm{cm}$ \\
\hline & Diameter of the plant & DPL & $\mathrm{cm}$ \\
\hline & Maturity of plants & MAT & Day \\
\hline & Pod weight & PWE & Number \\
\hline & Number of pods per plant & NPP & Number \\
\hline & Number of pods with one seed & N1S & Number \\
\hline & Number of pod with two seeds & N2S & Number \\
\hline & Pod length & PDL & $\mathrm{mm}$ \\
\hline & Pod width & PDW & $\mathrm{mm}$ \\
\hline & Weight of seeds per plant & WSP & g \\
\hline & Number of seeds per plant & NSP & Number \\
\hline & Seed length & SDL & $\mathrm{mm}$ \\
\hline & Seed width & SDW & $\mathrm{mm}$ \\
\hline & Weight of 100 seeds & WHS & $g$ \\
\hline & Shell rate & SHR & $\%$ \\
\hline & Yield per square meter & YSM & g. $m^{-2}$ \\
\hline
\end{tabular}




\section{RESULTS}

Variation of qualitative traits: All the qualitative characteristics observed as well as the different modalities and their frequencies (Table 3) show that, at the vegetative stage, $68.89 \%$ of the terminal leaflets of Bambara nut showed a lanceolate form. After harvest, observation of our accessions showed mostly yellowbrown pods (87.78\%) and brown pods (12.22\%). The texture of pod observed show that the smooth one was dominant with $55.56 \%$. A huge variability was observed with the seed colour with a predominance of cream seed $(31.11 \%)$. Colours such us dark brown seeds, black, dotted dark brown on cream background, light brown marbled spots on cream background, black rhombic spots on a cream background on the micro hair and not on the hairy ends, have the lowest proportions $(1.11 \%)$. The presence of eye was observed in the major part of accessions (74.44\%) studied while $25.56 \%$ of accessions were missing. The different colours and aspects of the eye were: irregular brown (3.33\%), circular grey $(2.22 \%)$, thick grey on both sides $(1.11 \%)$, butterfly grey $(52.22 \%)$, triangular grey $(7.77 \%)$, irregular black $(1.11 \%)$, dark red butterfly (6.67\%).

\section{Variation of quantitative traits}

Analysis of variance, range, mean value and frequency: The analysis of variance performed with 21 agro morphological characters (Table 4) show that most of the studied traits had significant differences at $1 \%$ level of probability except the characters day taken to maturity, Plant height and Pod width. Descriptive analysis shows that accessions take 5 to 9 days to emerge with an average of 54 leaves. The plant height ranging from $13.20 \mathrm{~cm}$ to $26.20 \mathrm{~cm}$, an average diameter of $30.16 \mathrm{~cm}$ and took about 80 days to reach the physiological maturation. The average number of pods per plant was 17.91 for an average weight of $233.3 \mathrm{~g}$. The average number of pods containing one seed and two seeds is respectively 15.71 and 0.56 . The average weight of seeds per plant was $160.8 \mathrm{~g}$ while the weight of 100 seeds was $57.62 \mathrm{~g}$. On average there is a pod rate and average grain yield of $4.10 \%$ and 59.32 g.m ${ }^{-2}$, respectively. The day to $50 \%$-flowering varied from 28 to 39 days. High values of coefficient of variation (CV> 30\%) were recorded for traits such as the number of pods containing two seeds $(138.20 \%)$, the pod width $(83.40 \%)$, the shell rate $(56.70 \%)$, yield $(50.20 \%)$, seed weight $(50.20 \%)$, pods weight $(47.90 \%)$, number of pods with one seed $(33.10 \%)$ and number of pods per plant $(33.00 \%)$. The variables such as days to emergence (10.30\%), emergence at 21st day $(11.60 \%)$, first flowering $(8.60 \%), 50 \%$ flowering $(10.08 \%)$, physiological maturity $(7.10 \%)$, weight of one hundred seeds $(13.60 \%)$, leaves number $(21.00 \%)$,plant height at maturity $(12.90 \%)$, diameter of plant $(11.40 \%)$, pod length $(11.20 \%)$, seed length $(7.30 \%)$ and seed width $(6.80 \%)$ have the low coefficient of variation. 
Table 3 : Frequencies of qualitative characters studied in 90 Bambara nut's accessions

\begin{tabular}{|c|c|c|}
\hline Characters & 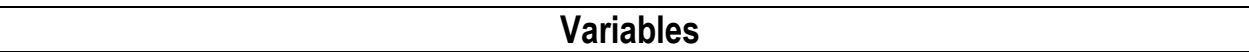 & Frequency $(\%$ \\
\hline \multirow{3}{*}{ Terminal leaflet form } & Elliptic & 30.00 \\
\hline & Lanceolate & 68.89 \\
\hline & Oval & 1.11 \\
\hline \multirow[t]{2}{*}{ Pod colour } & Brown & 12.22 \\
\hline & Yellowish brown & 87.78 \\
\hline \multirow[t]{10}{*}{ Pod texture } & Many grooves & 41.11 \\
\hline & Some grooves & 3.33 \\
\hline & Smooth & 55.56 \\
\hline & Dark brown & 1.11 \\
\hline & Cream & 31.11 \\
\hline & Black & 1.11 \\
\hline & Dotted dark brown on cream background & 1.11 \\
\hline & Dark purple & 5.56 \\
\hline & Light brownish red & 7.77 \\
\hline & Light red & 2.22 \\
\hline \multirow[t]{6}{*}{ Seed colour } & Brown streaks on cream background & 6.67 \\
\hline & Light brown marbled spots on cream background & 1.11 \\
\hline & Dark brown marbled spots on a cream background & 27.78 \\
\hline & Black marbled spots on a cream background & 8.89 \\
\hline & Dark brown rhombic spots on a cream background on the micro hair shaft & 4.44 \\
\hline & Black rhombic spots on a cream background on the micro hair and not on the hairy ends & 1.11 \\
\hline \multirow[t]{2}{*}{ Presence of eye } & Present & 74.44 \\
\hline & Absent & 25.56 \\
\hline \multirow[t]{7}{*}{ Colour and appearance of eye } & Irregular brown & 3.33 \\
\hline & Circular gray & 2.22 \\
\hline & Thick gray on both sides & 1.11 \\
\hline & Gray butterfly & 52.22 \\
\hline & Triangular gray & 7.77 \\
\hline & Irregular Black & 1.11 \\
\hline & Dark red butterfly & 6.67 \\
\hline
\end{tabular}



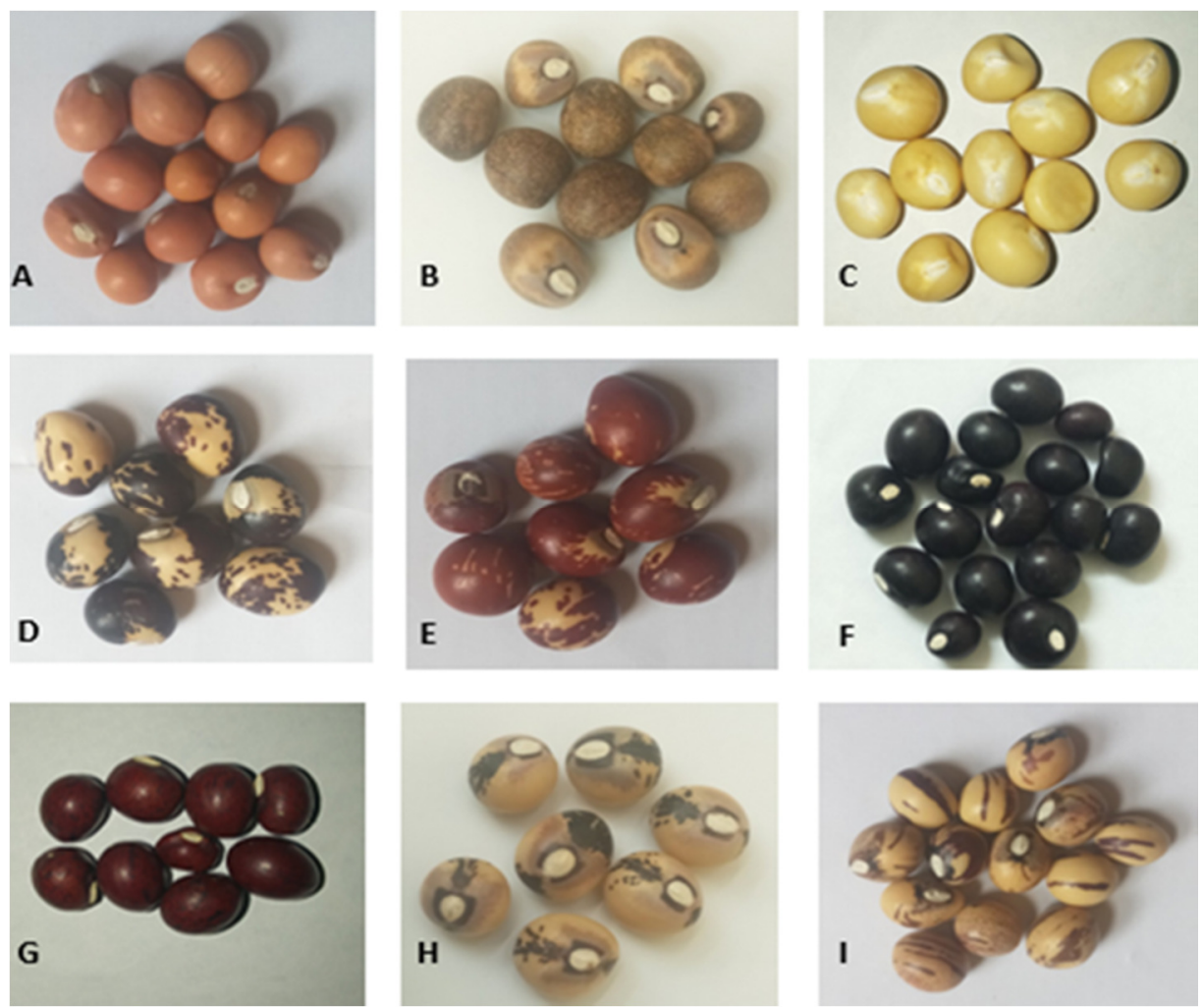

Figure 1: colours of seeds

A: Light red, B: Dotted dark brown on cream background, C: Cream, D: Black marbled spots on a cream background, E: Dark brown marbled spots on a cream background, F: Black, G: Dark purple, H: Black rhombic spots on a cream background on the micro hair and not on the airy ends, I: Brown streaks on cream background 
Table 4 : Result of the analysis of variance of 20 quantitative variables measured

\begin{tabular}{|c|c|c|c|c|c|c|}
\hline Characters & Minimum & Mean & Maximum & CV (\%) & $\mathbf{R}^{2}$ & F of Fisher \\
\hline DTE & 5.00 & 5.47 & 9.00 & 10.30 & 0.018 & $3.07^{* *}$ \\
\hline ETO & 7.00 & 16.17 & 20.00 & 11.60 & 0.004 & $5.45^{\star *}$ \\
\hline $\mathrm{FFL}$ & 22.00 & 27.80 & 39.00 & 8.60 & 0.007 & $3.03^{* *}$ \\
\hline HFL & 28.00 & 31.87 & 39.00 & 10.08 & 0.009 & 2.00 ** \\
\hline MAT & 77 & 80.27 & 84.00 & 7.10 & 0.055 & $0.96 \mathrm{~ns}$ \\
\hline NPP & 10.00 & 17.91 & 43.94 & 33.00 & 0.014 & $1.71^{* *}$ \\
\hline N1S & 5.00 & 15.71 & 48.10 & 33.10 & 0.011 & $1.31^{*}$ \\
\hline N2S & 0.00 & 0.56 & 7.53 & 138.2 & 0.002 & $0.29 * *$ \\
\hline PWE & 4.00 & 233.3 & 538.0 & 47.90 & 0.005 & $0.55^{\star *}$ \\
\hline WSP & 1.00 & 160.8 & 378.0 & 50.20 & 0.006 & $0.73^{* *}$ \\
\hline WHS & 16.00 & 57.62 & 111.00 & 13.60 & 0.072 & $11.82^{* *}$ \\
\hline SHR & 2.00 & 4.10 & 16.82 & 56.70 & 0.009 & $1.13^{* *}$ \\
\hline YPP & 30.00 & 59.32 & 146.3 & 50.20 & 0.006 & $0.73^{* *}$ \\
\hline NLP & 26.60 & 54.14 & 102.00 & 21.00 & 0.023 & $2.26^{* *}$ \\
\hline PHT & 13.20 & 19.11 & 26.20 & 12.90 & 0.057 & $1.23 \mathrm{~ns}$ \\
\hline DPL & 21.00 & 30.16 & 45.40 & 11.40 & 0.014 & $3.88^{* *}$ \\
\hline PDL & 9.81 & 16.27 & 22.00 & 11.20 & 0.004 & $2.45^{\star \star}$ \\
\hline PDW & 4.42 & 12.58 & 13.3 & 83.40 & 0.007 & $1.17 \mathrm{~ns}$ \\
\hline SDL & 8.74 & 11.16 & 14.56 & 7.30 & 0.026 & $3.33^{* *}$ \\
\hline SDW & 6.94 & 9.25 & 11.52 & 6.80 & 0.028 & $3.06^{\star *}$ \\
\hline
\end{tabular}

Legend: DTE : Days to emergence, ETO : emergence at twenty-one days after sowing, FFL : Days to first flowering, HFL : Days to $50 \%$ flowering, MAT : Maturity of plants, NPP : number of pods per plant, N1S : Number of pods containing one seed, N2S : Number of pod with two seeds, PWE : Pod weight, WSP : Weight of seeds per plant, WHS : Weight of 100 seeds, SHR : Shell rate, YSM : Yield per square meter, NLP : Number of leaves per plant, PHT : Plant height at maturity, DPL : Diameter of the plant, PDL : Pod length, PDW : Pod width, SDL : Seed length, SDW : Seed width, F : coefficient of Fischer, CV : coefficient of variation, $\mathrm{R}^{2}$ : coefficient of determination, ns : not significant, *: Indicate significant difference at $5 \%,{ }^{* *}$ : Indicate significant difference at $1 \%$. 
Association of Characters: The Pearson correlation matrix in Table 5 shows 53 significant correlations at $5 \%$ level. The most significant correlations were positive correlations between seed yield and weight $(r=$ 0.995), pod number and number of pods with one seed $(r=0.977)$, between pod weight and seed weight $(r=$ $0.956)$ and pod yield and weight $(r=0.952)$. Interesting correlations with low correlation coefficients $(r<0.6)$ were also observed between plant diameter which was significantly and positively correlated with yield $(r=$ 0.258). The height of the plant at maturity was correlated positively and significantly with seed weight $(r=0.251)$ and yield $(r=0.251)$. Days to $50 \%$ flowering was positively and significantly correlated with the number of pods with one seed $(r=0.250)$ and number of pods was positively and significantly correlated pod length $(r=0.258)$. Some negative correlations have been observed between days to emergence at twentyone day after sowing ( $r=-0.473)$, between days to emergence and number of pod per plant $(r=-0.418)$, between number of pod with two seeds and pod length $(r=-0.410)$. 
Table 5 : Correlations between the quantitative characters

\begin{tabular}{|c|c|c|c|c|c|c|c|c|c|c|c|c|c|c|c|c|c|c|c|c|}
\hline Variables & DUE & ETO & $\mathrm{FFL}$ & HFL & MAT & NPP & N1S & N2S & PWE & WSP & WHS & PDR & YPP & NLP & PHT & DPL & PDL & PDW & SDL & SDW \\
\hline DUE & 1 & & & & & & & & & & & & & & & & & & & \\
\hline ETO & $-0.473^{* *}$ & 1 & & & & & & & & & & & & & & & & & & \\
\hline $\mathrm{FFL}$ & $0.515^{* *}$ & -0.181 & 1 & & & & & & & & & & & & & & & & & \\
\hline $\mathrm{HFL}$ & 0.372 & -0.095 & $0.680^{* *}$ & 1 & & & & & & & & & & & & & & & & \\
\hline MAT & 0.189 & 0.124 & 0.184 & 0.206 & 1 & & & & & & & & & & & & & & & \\
\hline NPP & $-0.418^{* *}$ & $0.549^{* *}$ & -0.374 & -0.274 & -0.225 & 1 & & & & & & & & & & & & & & \\
\hline N1S & \begin{tabular}{|l|}
-0.363 \\
\end{tabular} & $0.532^{* *}$ & $\begin{array}{l}-0.342 \\
\end{array}$ & -0.250 & \begin{tabular}{|l|}
-0.226 \\
\end{tabular} & $0.977^{* *}$ & 1 & & & & & & & & & & & & & \\
\hline $\mathrm{N} 2 \mathrm{~S}$ & -0.371 & \begin{tabular}{|l|}
0,322 \\
\end{tabular} & -0.214 & -0.131 & -0.103 & $0.435^{\star *}$ & 0.339 & 1 & & & & & & & & & & & & \\
\hline PWE & -0.152 & $0.437^{* *}$ & -0.145 & -0.140 & -0.045 & $0.696^{* *}$ & $0.731^{* *}$ & 0.174 & 1 & & & & & & & & & & & \\
\hline WSP & -0.230 & $0.484^{* *}$ & -0.235 & -0.187 & -0.053 & $0.792^{* *}$ & $0.810^{* *}$ & 0.296 & $0.956^{* *}$ & 1 & & & & & & & & & & \\
\hline WHS & 0.158 & 0.001 & 0.011 & -0.069 & 0.046 & 0.078 & 0.150 & -0.273 & $0.660^{* *}$ & $0.548^{* *}$ & 1 & & & & & & & & & \\
\hline SHR & -0.006 & 0.211 & -0.007 & -0.062 & -0.047 & 0.396 & $0.451^{* *}$ & -0.085 & $0.791^{* *}$ & $0.673^{* *}$ & $0.668^{* *}$ & 1 & & & & & & & & \\
\hline YSM & -0.243 & $0.499^{* *}$ & -0.240 & -0.191 & -0.053 & $0.807^{* *}$ & $0.825^{\star *}$ & 0.309 & $0.952^{\star \star}$ & $0.995^{\star *}$ & $0.537^{* *}$ & $0.673^{* *}$ & 1 & & & & & & & \\
\hline NLP & 0.252 & -0.135 & 0.320 & 0.219 & 0.049 & 0.065 & 0.105 & -0.007 & 0.386 & 0.305 & 0.393 & $0.470^{* *}$ & 0.304 & 1 & & & & & & \\
\hline PHT & 0.232 & -0.046 & 0.194 & 0.290 & 0.107 & 0.041 & 0.073 & -0.121 & 0.366 & 0.251 & 0.339 & $0.441^{* *}$ & 0.251 & $0.581^{* *}$ & 1 & & & & & \\
\hline DPL & 0.333 & -0.001 & 0.362 & 0.355 & 0.173 & 0.002 & 0.038 & -0.141 & $0.404^{* *}$ & 0.260 & 0.344 & $0.526^{* *}$ & 0.258 & $0.654^{* *}$ & $0.737^{* *}$ & 1 & & & & \\
\hline PDL & 0.300 & $-0,141$ & 0,311 & 0,239 & 0,038 & $-0,258$ & $-0,181$ & $-0,410^{* *}$ & 0,290 & 0,122 & $0,643^{* *}$ & $0,502^{* *}$ & 0,109 & $0,426^{* *}$ & $0,579^{* *}$ & $0,550^{* *}$ & 1 & & & \\
\hline PDW & 0.057 & $-0,041$ & $-0,017$ & $-0,049$ & 0,014 & 0,074 & 0,089 & $-0,040$ & 0,185 & 0,211 & 0,237 & $0,447^{* *}$ & 0,205 & 0,213 & 0,069 & 0,124 & 0,194 & 1 & & \\
\hline $\mathrm{SDL}$ & 0.104 & $-0,062$ & 0,090 & 0,057 & 0,065 & $-0,067$ & $-0,004$ & $-0,297$ & $0,483^{* *}$ & 0,356 & $0,760^{* *}$ & $0,560^{* *}$ & 0,347 & $0,421^{* *}$ & $0,496^{* *}$ & $0,449^{* *}$ & $0,814^{* *}$ & 0,171 & 1 & \\
\hline SDW & 0.127 & 0,134 & $-0,034$ & $-0,025$ & 0,287 & 0,003 & 0,030 & $-0,091$ & $0,411^{* *}$ & 0,352 & $0,545^{\star *}$ & $0,403^{* *}$ & 0,343 & 0,202 & 0,273 & 0,276 & 0,387 & 0,148 & $0,555^{\star *}$ & 1 \\
\hline
\end{tabular}

Legend: DTE : Days to emergence, ETO : emergence at twenty-one days after sowing, FFL : Days to first flowering, HFL : days to $50 \%$ flowering, MAT : maturity of plants, NPP : number of pods per plant, N1S : Number of pods with one seed, N2S : Number of pod with two seeds, PWE : Pod weight, WSP : Weight of seeds per plant, WHS : Weight of 100 seeds, SHR : Shell rate, YSM : Yield per square meter, NLP : Number of leaves per plant, PHT : Plant height at maturity, DPL : Diameter of the plant, PDL : Pod length, PDW : Pod width, SDL : Seed length, SDW : Seed width, ${ }^{* *}$ : significant correlation at 0.05 level. 
Principal Component Analysis: The Principal Component Analysis (PCA) (figure 2) performed showed variability within the Bambara nut accessions. The cumulative values of variance of the first two factors (F1 and F2) for the 20 quantitative variables were $55.598 \%$ (Table 6). The factor $\mathrm{F} 1$ has an eigenvalue of 6.675 and alone accounts for $31.784 \%$ characters variation. $\mathrm{F} 1$ factor is associated with number of pods ( $r=0.691$ ), number of pods with one seed $(r=0.727)$, pod weight $(r=0.964)$, seed weight $(r$ $=0.933)$, weight of one hundred seeds $(r=0.659)$, shell rate $(r=0.790)$, yield $(r=0.935)$, pod and seed width ( $r$
$=0.230)$ and seed width $(r=0.471)$. The factor F2 contributes $23.814 \%$ to total variation and is associated with characters such as days to emergence $(r=0.661)$, emergence at 21 days after sowing $(r=-0.518)$, days to first flowering (PFLO with $r=0.579$ ), days to $50 \%$ flowering (50FLO with $r=0.475)$, days to maturity ( $r=$ $0.218)$, number of pods with two seeds $(r=-0.552)$, number of leaves $(r=0.526)$, plant height $(r=0.571)$, plant diameter $(r=0.619)$, pod length $(r=0.772)$ and seed length $(r=0.608)$. The squares of Mahalanobis distances from this analysis show that these groups are different at the $5 \%$

Table 6: Correlations between the 20 quantitative characters and the factors $(F)$ of PCA performed on accessions

\begin{tabular}{lccc}
\hline & Principal components & & \\
\hline Characters & F1 & F2 & F3 \\
\hline Eigen value & 6.675 & 5.001 & 1.870 \\
\hline \% variance & 31.784 & 23.814 & 8.904 \\
\hline \% cumulative & 31.784 & 55.598 & 64.502 \\
\hline DUE & -0.193 & 0.661 & 0.127 \\
ETO & 0.510 & -0.518 & 0.386 \\
FFL & -0.163 & 0.579 & 0.561 \\
HFL & -0.134 & 0.475 & 0.660 \\
MAT & -0.029 & 0.218 & 0.345 \\
NPP & 0.691 & $-0,594$ & 0.378 \\
N1S & 0.727 & -0.523 & 0.105 \\
N2S & 0.174 & -0.552 & 0.082 \\
PWE & 0.964 & -0.021 & 0.280 \\
WSP & 0.933 & -0.203 & -0.017 \\
WHS & 0.659 & 0.468 & -0.392 \\
SHR & 0.790 & 0.319 & -0.097 \\
YSM & 0.935 & -0.219 & -0.002 \\
NLP & 0.431 & 0.526 & 0.212 \\
PHT & 0.444 & 0.571 & 0.235 \\
DPL & 0.451 & 0.619 & 0.365 \\
PDL & 0.363 & 0.772 & -0.154 \\
PDW & 0.230 & -0.203 \\
SDL & 0.545 & -0.316 \\
SDW & 0.471 & 0.608 & -0.188 \\
\hline LEg & 0.334 &
\end{tabular}

Legend: DTE : Days to emergence, ETO : Emergence at twenty-one days after sowing, FFL : Days to first flowering, HFL : days to $50 \%$ flowering, MAT : maturity of plants, NPP : number of pods per plant, N1S : Number of pods with one seed, N2S : Number of pod with two seeds, PWE : Pod weight, WSP : Weight of seeds per plant, WHS : Weight of 100 seeds, SHR : Shell rate, YSM : Yield per square meter, NLP : Number of leaves per plant, PHT : Plant height at maturity, DPL : Diameter of plant, PDL : Pod length, PDW : Pod width, SDL : Seed length, SDW : Seed width. 
Kambou et al., J. Appl. Biosci. 2020 Agro-morphological characterization of Bambara nut accessions [Vigna subterranea (L) Verdcourt] from Burkina Faso

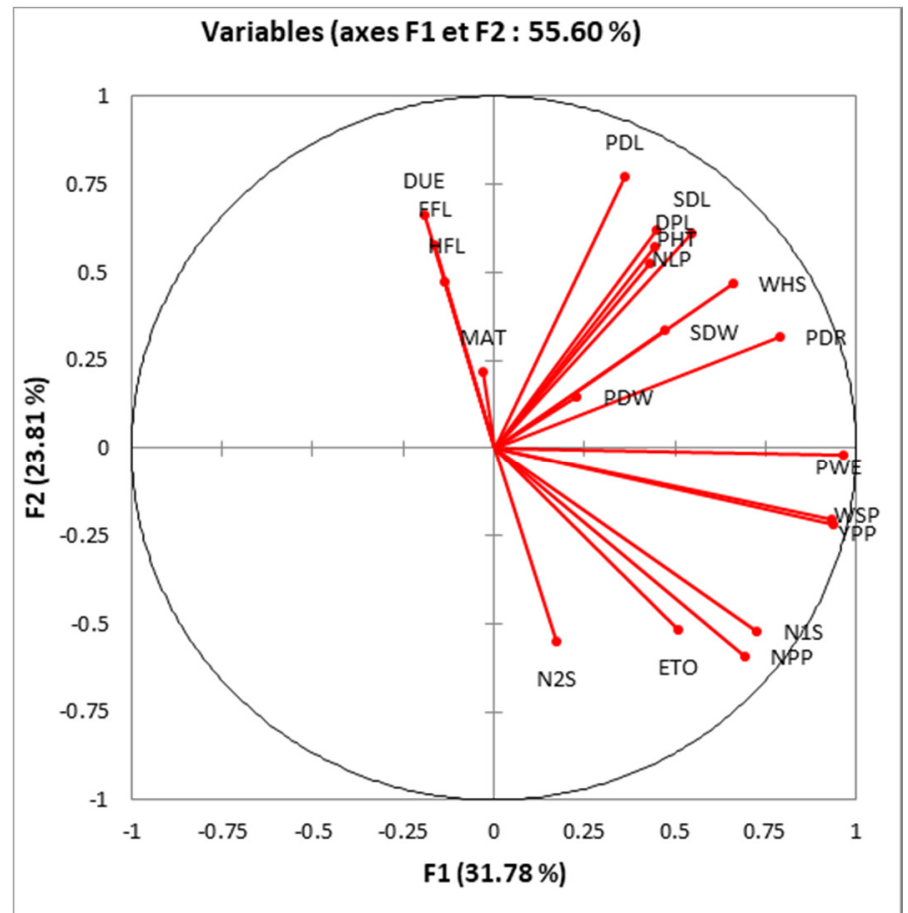

Figure 2: Measured variables projection in the plane formed by the first 2 canonical axes of principal component analysis (PCA)

The gathering of accessions was made using Agglomerative Hierarchical Clustering (AHC) based on Euclidean distances between individuals. The dendogram (figure 4) shows 4 distinct groups. The first group consists of 32 accessions from Sudan-Sahelian, Sudanian, Sahelian zones and INERA/CREAF, with respectively 16, 7, 6 and 3 accessions. The second group consists of 25 accessions and among theme 19 are from Sudan-Sahelian, 4 from Sahelian and 2 from the Sudanian. The third group consists of 30 with accessions, 14 from Sudan-Sahelian, 8 from Sahelian, 6 from Sudanian and 2 from INERA/CREAF. The fourth group consists of 3 accessions, 2 from Sudanian and one from INERA/CREAF. 


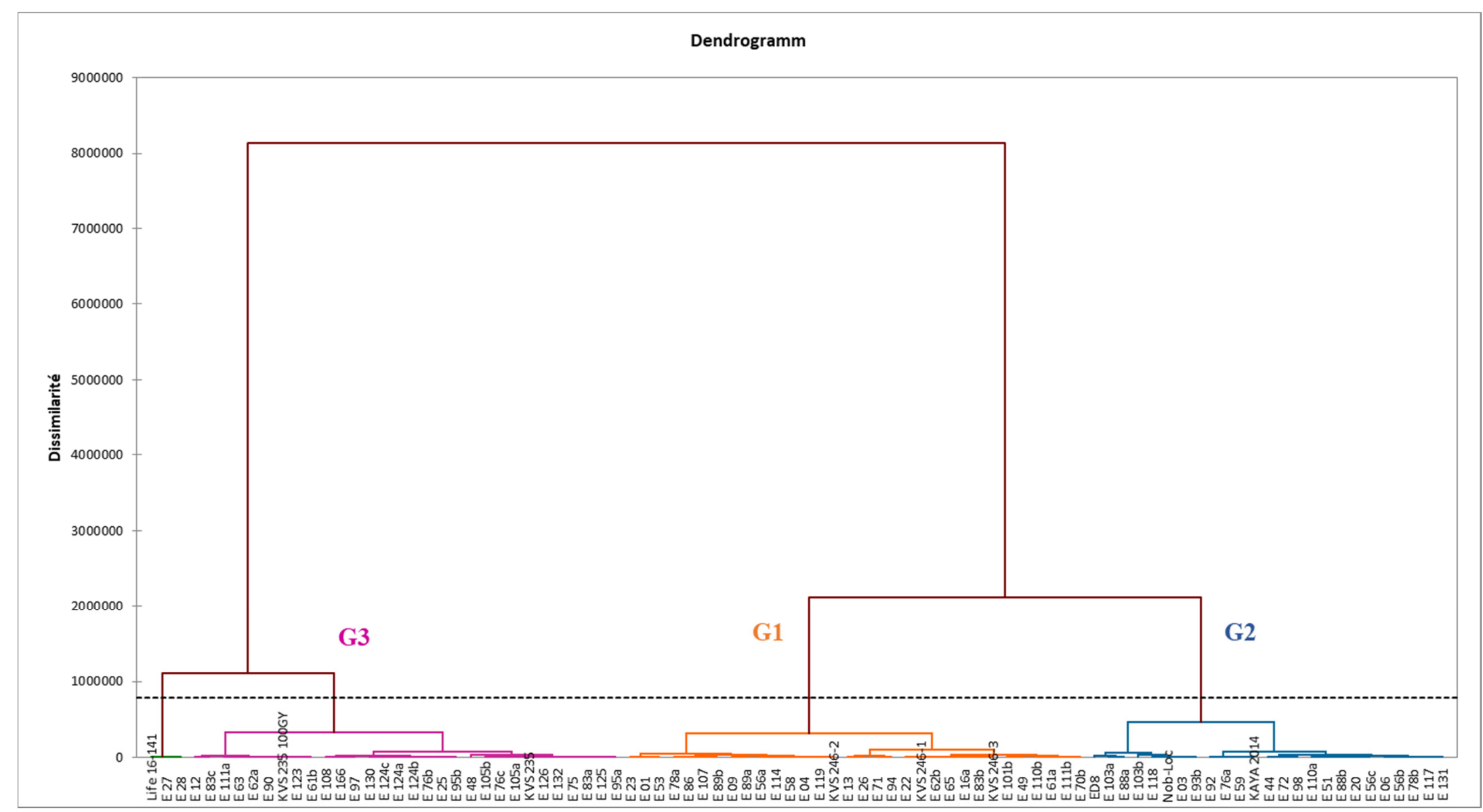

Figure 3: Dendogram showing the clustering pattern in V. subterranea accessions based on morphometric and agronomic traits 
Kambou et al., J. Appl. Biosci. 2020 Agro-morphological characterization of Bambara nut accessions [Vigna subterranea (L) Verdcourt] from Burkina Faso

Table 7: Average performance of $\mathrm{V}$. subterranea groups from the AHC

\begin{tabular}{lllllll} 
Group & I & II & III & IV & Pr of F & Siginif. \\
\hline Effective & 32 & 25 & 30 & 3 & & \\
NPP & 17.83 & 17.57 & 18.68 & 17.87 & 0.031 & $*$ \\
N1S & 17.18 & 17.09 & 18.06 & 17.51 & 0.026 & $*$ \\
WHS (g) & 56.48 & 55.65 & 61.35 & 50.5 & $<0.0001$ & $*$ \\
SDL (mm) & 11.05 & 11.09 & 11.35 & 10.99 & 0.034 & $*$
\end{tabular}

Legend: NPP: number of pods per plant, N1S: Number of pods with one seed, WHS: Weight of 100 seeds, SDL: Seed length, *: Indicate significant difference at $5 \%$ level, ${ }^{* *}$ : Indicate significant difference at $1 \%$ level.

\section{DISCUSSION}

Analysis of the qualitative characters showed a great variability within 90 Bambara nut accessions. Most of the accessions were cream-colored seeds (31\%). This high rate of cream coloured seeds is also reported by Ouoba et al. (2016) who explain that the high rate of cream coloured seeds is due to people preferences, their aesthetical, their market value and the fact that they are easy to cook. Work led by Abu and Buah (2011) on 22 accessions from Poyentanga in Ghana showed that cream coloured seed coat is popular and preferred for consumption because of its commercialization and its homogeneous attributes for production because seeds of this colour tend to produce seeds with homogeneous attributes. Several variants of pod colour and texture were observed with strong dominance for yellowish-brown and smooth pods, respectively. The smooth-textured pods would easily lend themselves to the process of gumming compared to pods with grooves. However, Mohammed et al. (2016) demonstrated that yellowish pods with little grooves are dominant in their collection of 49 accessions. The majority of this study accessions $(74.44 \%)$ have an eye, more than half have a grey colour in the shape of butterfly. These criteria are appreciated by the farmers and they take this into account for the multiplication and valorisation of these accessions compared to others. Ndiang et al. (2012) have also observed in their work on ten accessions, seeds with a grey eye in the shape of a butterfly. These different morphological characters studied that Bambara nut accessions grown in Burkina Faso has enormous genetic variations. This is in accordance with Massawe et al, (2005)] who reported significant variation in Bambara nut grown in Africa. The result of variance analysis showed significant differences at $5 \%$ and $1 \%$ level of probability among the accessions for studied characters except maturity of plant, Plant height and Pod width. There is considerable agro morphological diversity within the Bambara nut accessions grown in Burkina Faso. The diversity observed in the current research is in agreement with the report of Ouédraogo et al. (2008) who reported significant variability within 310 accessions collected in Burkina Faso. Mohammed et al, 2016 have established the presence of sufficient variations between some agronomic and morphological traits among 99 Bambara nut accessions in South Africa. According to Touré et al. (2013) who have observed a variability between 15 morphotypes of Bambara nut in Ivory Coast for the plant height, number of leaves, the variability of growth could be related to the efficiency of interception of the solar radiation and especially to the biological efficiency of conversion of this radiation into biomass. The high values of the determination coefficients $\left(R^{2}\right)$ observed in traits such as the weight of one hundred seeds, the height of the mature plant and the physiological maturation contribute to a variation between the accessions and are therefore responsible for the agro morphological variation. The large amplitude of variation reflect great heterogeneity of the accessions for the concern characters. These variations can be explained by the diverse origin of accessions. Nonetheless, a large variation with in accessions for traits such as yield and physiological maturity could contribute to the high-yielding varietal selection, by favouring research on high-yielding accessions with a relatively short duration maturation. The number of days at emergence between 5 and 8 days differs from that observed by Djè et al. (2005) which is between 7 and 10 days. This could be explained by a difference in soil type and/or rainfall during and after sowing (600 $\mathrm{mm}$ ). For Touré et al. (2013), the variability of response expressed a heterogeneity in the germination quality of the seeds which would result mainly from their sanitary 
and physiological states. According to Paul et Bruce (2008), Thomas et al. (2009), early emergence is an important agronomic trait that could help good production of Bambara nut. In this study the flowering amplitude entered 20 to 45 days. The good rainfall can explain it in this period. Djè et al. (2005) observed a higher (41 to 56 days) for four cultivars studied. The number of varieties (90) studied from different geographical origins could explain these different results. The flowering date is a component of adapting a variety to an environment. They are influenced by genetic and/or environmental factors that due to some complex interactions according to Ishiyaku et al. (2005) and Uarrota et al. (2010). It is a parameter of great importance that also determines the yield of the plant in annual crops such as Vigna subterranea (Kumaga et al., 2003, Makanda et al., 2009, Onwubiko et al., 2011). The average number of leaves (54.14) is lower than found by Molosiwa (2012) who counted 79.4 leaves for 35 accessions concerned in United Kingdom. The difference in the plant material used and the soil and climate conditions can influence the expression of these characters. The average values of the length and width of the pods and seeds are close to those of Ouédraogo et al., 2008 which characterized 310 accessions collected in Burkina. These similarities of our results is due to the fact the tests were implemented in similar agro ecological zones and having almost the same rainfall data. The plants had a shorter maturation ( 80 days) and a diameter between 21 and $45.60 \mathrm{~cm}$ and the heights varied from 13.20 to $16.20 \mathrm{~cm}$. According to Touré et al. (2013), this difference of maturity could be explained by nutritional and genotypic specificity. Bode et al. (2012) have obtained higher values on 124 accessions from IITA sown in lbadan (Nigeria) where the physiological maturation time were longer and where the soil type, temperature, relative humidity and rainfall data were better than this study. In this study, average values of number of pods per plant (17.91) and pods weight per plant (107.2g) are significantly higher compared to 14 accessions studied by Amadou et al. (2018) in Niger who found an average of 13.62 pods per plant and an average pods weight per plant of $10.8 \mathrm{~g}$. The size of sample in this work and the good rainfall of the year of the study could have a considerable influence on theses parameters. The rainfalls were $486 \mathrm{~mm}$ during Amadou et al. (2018) study. The weight of 100 seeds $(57.62 \mathrm{~g})$ is lower than it $(83.46 \mathrm{~g})$ found by Jonah et al. (2012) in Nigeria on 12 cultivars of Bambara nut. The high values of shell rate in some accessions show that the thickness of their shell is greater compared to the thickness of the seed. The accessions studied showed a yield of 59.32 g.m. ${ }^{-2}$. These results are the consequence of the variation of performance parameters due to biotic factors. These yields differ greatly from those of Ouédraogo et al., 2008, who obtained yields per square meter of $11 \mathrm{~g} \cdot \mathrm{m}^{-2}$. This study findings are in agreement with those of Shegro et al. (2013), who explain this variation in yield by the influence of environment and genotype of accessions.

The correlation coefficient is an important parameter in plant breeding because it measures the degree of genetic association or not between two or more traits (Jonah et al., 2014). The yield per square meter is a very important parameter in a breeding program. Shell rate (SHR), number of pods per plant (NPP), pod weight per plant (PWE), number of pod with one seed (N1S) and seed weight per plant (WSP) strongly correlated Positively to yield shows that accessions with a high number of pods per plant, to number of pod containing one seed, high pod weight, seed weight and pod rate, are those that produce good yields. However, days to emergence, date to first flowering, day to $50 \%$ flowering (HFL), maturity (MAT) and yield per square meter (YSM) per plant showed a negative correlation indicating that the longest periods of vegetation result in low yields corroborating the results of Ouedraogo et al. 2008. These results could be explained by the spatiotemporal distribution of rainfall and the cycle of different sample. Bonny and Djè, 2011 in their work showed that accessions which have late maturation, are more vigorous and give the best yields, while low yields result from accessions which have early maturation with the weakest vegetative characteristics. That is why Kadams and Sajo (1998) described yield as a measure and an indication of good agronomic performance. PCA indicates that $55.60 \%$ of the total variability were expressed by the first two axes. The F1 axis explains $31.78 \%$ of this variability while the $\mathrm{F} 2$ axis shows 23.81\%. The DTE, ETO, FFL, HFL, MAT, N2S, NLP, PHT, DPL, PDL and SDL variables are significantly related to the second axis. This axis can be called the vegetative development axis. On the other hand, variables such as NPP, N1S, PWE, WSP, WHS, PDR, YPP, PDW and SDW are related to first axis which expresses the components of performance. As indicate by the four groups obtained from AHC there is a considerable difference in the variability pattern in Bambara nut grown in Burkina Faso. Gathering is based mainly on yield related traits such as yield per square meter, pod length, seed length, number of pods 
per plant, number of pod with one seed, shell rate, diameter of the plant which are discriminating at the threshold of $5 \%$ and weight of one hundred seeds discriminating at the threshold of $1 \%$. The works carried out by Unigwé et al. (2016) yielded four groups based on yield, number of leaves per plant, and plant height. Yield is the most discriminating agronomic parameter within Bambara nut accessions. The first group consists of 32 accessions with early emergence, highest pod weights, good yield and longest pods. Group 2 formed by 25 accessions has average values for all characters. Group 3 with 30 accessions is the one that stands out with strong values on almost all the characters studied. As for group 4 composed of 3 accessions, their difference is due to the very low value of their seed weight per plant. The groups 1, 2, 3 and 4 obtained are formed by accessions of different origins. The clusters are based on the characters such as number of pod per plant, number of pods with one seed, weight of 100 seeds and seed length. This accession has a long duration of maturity and is a very high yield. The grouping model of accessions can be used as a basis for the selection of potential parents with interesting agro-morphological characteristics for the improvement of the plant. The accessions from the Sudan-Sahelian zone have strong agronomic and productive potential that would constitute a material of choice to develop genotypes of Bambara nut that would meet the needs of producers and consumers. In view of climate change

\section{CONCLUSION AND APPLICATION OF RESULTS}

This study on 90 Bambara nut's accessions showed existence of significant agro morphological variability. That would result from the expression of high genotypic heterogeneity and also the influence of environmental factors. Some characters present high correlations. In addition the result showed how Bambara nut diversity is structured. The assessment of morphological variability is the first step in the evaluation of genetic diversity for characterized by the shortening of rainy seasons, it is necessary for the breeder to develop early varieties, stable with high productivity. The morphological and phenological dissimilarities observed show that in the respective agroecosystems, evolutionary processes control the accessions. Agroecosystems are likely to exercise very variable selective pressures on genotypes (Doku et Karikari, 1971; Sadiki et Jarvis, 2005) as well as anthropogenic pressures (Robert et al., 2004). The agro morphological characterization of the accessions studied showed that the accessions of the Sudano-Sahelian zone are more productive. Those in group 3 had the best agronomic potential. The maturation cycles of high yielding accessions range from 79 to 83 days. However, the accessions E 78b, E $103 a$ and $E 49$ have early maturation respectively of 65.50; 65.75 and 66.50 days. Touré et al. (2013), obtained a longer maturation cycle of 86 to 124 days. Rainfall is a determining factor in the production of Bambara nut. However, rainfall is often less than 800 $\mathrm{mm} /$ year in production areas. To this end, improved productivity and increased production of Bambara nut in Burkina Faso should take into account accessions that combine high pod characteristics per plant, high yield and a short maturation cycle. It should combine carefully appropriate crop options according to the production context in order to maximize the yield potential of cultivars with high productive value.

breeding programs. The strong correlations observed between morphological and agronomic parameters make characters concerned important indices to be used in improvement programs. This study should be supplemented by using molecular markers to provide a deeper analysis of Bambara nut genetic diversity in Burkina Faso.

\section{ACKNOWLEDGEMENTS}

We appreciate the financial support of the McKnight foundation in this work

\section{REFERENCES}

Heller, J., F. Begemann and J. Mushonga, Editors. 1997. Bambara groundnut (Vigna subterranea (L.) Verdc.). Promoting the conservation and use of underutilized and neglected crops. 9. Proceedings of the workshop on Conservation and Improvement of Bambara Groundnut (Vigna subterranea (L.) Verdc.), 14-16
November 1995, Harare, Zimbabwe. Institute of Plant Genetics and Crop Plant Research, Gatersleben/Department of Research \& Specialist Services, Harare/International Plant Genetic Resources Institute, Rome, Italy. Ouédraogo $M$, Ouédraogo JT, Tignéré JB, Balma $D$, Dabiré CB, Konaté G, 2008. Characterization 
and Evaluation of accessions of Bambara groundnut [Vigna subterranea (L.) Verdcourt] from Burkina Faso. Sciences \& Nature. 5 (2): 191-197.

Brink M., Grubben G.J.H., Belay G., Agrooh., 2006. Ressources végétales de l'Afrique tropicale 1: Céréales et légumes secs. Edition M. Brink. Wageningen University, P.O. Box 341, 6700 AH Wageningen, Netherlands, $328 \mathrm{p}$.

Faostat, 2016. Accédé le 02 Février 2018. http://www.fao.org/faostat/fr/\#data/QC

Mbaiogaou A., 2015. Etude de quelques polyphénols d'une légumineuse du genre Vigna: Vigna Subterranea (Fabaceae) .190 $p$

Gueye M., 1989. Amélioration de la production du voandzou au Sénégal par la fixation biologique de l'azote. Cahier d'information de l'Institut Sénégalais de recherche agricole, BP 3120 Dakar, Sénégal. Vol 3. No1. 7p.

Nadembèga S., 2016. Productions vivrières et sécurité alimentaire au Burkina Faso: cas du voandzou dans trois communes des trois zones agroécologiques. Diplôme de Master 2, Université Catholique de l'Afrique de l'Ouest, Bobo Dioulasso. 90p.

Ouédraogo M, Zagré BM, Jørgensen S, Liu F. 2012. Effect of mounding times on yield of Bambara groundnut (Vigna subterranea (L.) Verdc.) landraces in Sahel-Burkina Faso. African Journal of Agricultural Research., 7(32):45054511. DOI: http://dx.doi.org/ 10.5897/AJAR12.974

IPGRI, IITA. et Bamnet., (2000). Descriptors for bambara groundnut (Vigna subterranea). International Plant Genetic Resources Institute, Rome Italy; International Institute of Tropical Agriculture, Ibadan, Nigeria; The International Bambara Groundnut Network, Germany. $57 \mathrm{pp}$.

Ouoba $A$, Ouédraogo $M$, Sawadogo $M$, Nadembèga $S$ (2016). Aperçu de la culture du voandzou (Vigna subterranea (L.) Verdcourt) au Burkina Faso: enjeux et perspectives d'amélioration de sa productivité. Int. J. Biol. Chem. Sci. 10(2): 652-665

Abu H. B., Buah S. S. J., 2011. Characterization of Bambara Groundnut Landraces and Their Evaluation by Farmers in the Upper West Region of Ghana. Journal of Developments in Sustainable Agriculture. 6: 64-74.
Mohammed M. S., Shimelis H. A. and Laing M.D. Phenotypic characterization of diverse Bambara groundnut (Vigna subterranea) [L] Verdc.) germplasm collections through seed morphology. Genet Resour Crop Evol (2016) 63: 889-899.

Ndiang Z, Bell J M, Missoup A D, Fokam P E et Amougou A, 2012. Étude de la variabilité morphologique de quelques variétés de voandzou [Vigna subterranea (L.) Verdc] au Cameroun. Journal of Applied Biosciences 60: 4410- 4420

Massawe FJ, Mwale SS, Azam-Ali SN, Roberts JA, 2005. Breeding in Bambara groundnut [Vigna subterranea (L.) Verdc.]: strategic considerations. African Journal of Biotechnology 4(6): 463-471.

Touré Y, Koné' M, Silué' S, Kouadio YJ (2013). Prospection, collecte et caracterisation agromorphologique des morphotypes de voandzou [Vigna subterranea (L.) Verdc. (Fabaceae)] de la zone savanicole en Côte d'Ivoire. Eur Sci J 9(24):308-325

Djè Y., Bonny B. S., Bi I. A. Z., 2005. Observations préliminaires de la variabilté entre quelques morphotypes de voandzou (Vigna subterranea L. Verdc., Fabaceae) de Côte d"Ivoire. Biotechnol., Agron., Société et Environ (2005) 9, 1-16.

Paul G. Jefferson and Bruce Coulman (2008). Early seedling growth and forage production of diploid and tetraploid crested wheatgrass. Canadian journal of plant science, pp. 687692.

Production in Zimbabwea. African Crop Science Journal, Vol. 16, No. 3, pp. 175 - 183.

Thomas J. M. G., Prasad P. V. V., Boote K. J \& Allen Jr. L. H. (2009). Seed Composition, Seedling Emergence and Early Seedling Vigour of Red Kidney Bean Seed Produced at Elevated Temperature and Carbon Dioxide. Journal of Agronomy \& Crop Science (2009).

Ishiyaku M.F., Singh B.B., Craufurd P. Q., 2005. Inheritance of time to flowering in cowpea (Vigna unguiculata (L.) Walp.). Euphytica, 142: 291-300.

Uarrota, 2010. Response of cowpea (Vigna subterranea (L.) walp.) to water stress and phosphorus fertilization. Journal of Agronomy. 9: 87-91. 
Kumaga F.K., S. G. K. Adiku and K. Ofori, 2003. Effect of Post-flowering Water Stress on Dry Matter and Yield of Three Tropical Grain Legumes. International journal of agriculture \& biology, 1560-8530/2003/05-4-405-407.

http://www.ijab.org.

Makanda I., P. Tongoona, R. Madamba, D. Icishahayo and J. Derera, 2009. Path Coefficient Analysis of Bambara Groundnut Pod Yield Components at Four Planting Dates. Research Journal of Agriculture and Biological Sciences, 5(3): 287292.

Onwubiko N. I. C., Odum O.B., Utazi C.O., Poly-Mbah P.C., 2010. Studies on the Adaptation of Bambara Groundnut [Vigna Subterranea (L.) Verdc] in Owerri southeastern Nigeria pp 7986.

Molosiwa O. O., 2012. Phd thesis, University of Notttingham, 259 pages.

Bode A. Olukolu, Sean Mayes, Florian Stadler, N. Quat $\mathrm{Ng}$, lyiwole Fawole, Dumet Dominique, Sayed N. Azam-Ali, Albert G. Abbott, Chittaranjan Kole, 2012. Genetic diversity in Bambara groundnut (Vigna subterranea (L.) Verdc.) as revealed by phenotypic descriptors and DArT marker analysis. Genet Resour Crop Evol, 59:347-358.

Amadou H. I., Agali A., Sani D. O., Souleymane B. K. (2018). Variabilité morphologique et agronomique des morhotypes de voandzou (Vigna subterranea (L.) cultivés dans la zone sahélienne du Niger. European Scientific Journal ESJ. 14. 10. 19044/esj. 2018. V14n36p377

Jonah P M, Aliyu B, Kadams A M, Wamannda D T (2012). Variation in pod yield characters and heritability estimates in some cultivars of Bambara groundnut (Vigna subterranea (L.) Verdc. Acad J Plant Sci 5(2):50-55

Shegro A. G, Jansen Van Rensburg W. S. \& Adebola P. O., 2013. Multivariate analysis of nutritional diversity in sorghum land race accessions from Western Ethiopia. J Biol. Sci. 13(12): 67-74.

Jonah Pm, Abimiku O. E \& Adeniji O. T. 2014. Multivariate analysis and character association on the growth and yied of Bambara Groundnut in Mubi, Adamawa State, Nigeria. Internationnal Journal of Management and Social Research, 3, 2.

Bonny S. B., Djè Y., 2011. Variabilité morphologique et agronomique des variétés traditionnelles de voandzou [Vigna subterranea (I.) verdc. (Fabaceae)] de Côte d'lvoire. Journal of Applied Biosciences 41: 2820 - 2835.

Kadams, A.M. and A.A. Sajo, 1998. Variability and correlation studies in yield and yield components in Bambara groundnut (Vigna subterrenea L. Verdc). Journal of Applied Science and Management, 2: 66-70.

Unigwé A. E., Gerrano A. S., Adebola P., Pillay M.,2016. Morphological variation in selected accessions of Bambara Groundnut (Vigna subterranea L. Verdc.) in South Africa. Journal of Agriculture Science, Vol 8, No 11, 19169752.

Doku E V., Karikari S., 1971. The role of ants in pollination and pod production of Bambara groundnut. Econ. Bot. 25, p. 357-362.

Sadiki M, Jarvis D, 2005. Conservation in situ de la diversité génétique des cultures par sa gestion à la ferme dans les agroécosystèmes marocains. Les Actes du BRG, 5: 445-464.

Robert T., Luxereau A., Mariac C., Ali K., Allinne C., Bani J., Beidari Y., Bezançon G., Gayeux S, Couturon E, Dedieu V, Sadou M, Seydou M, Seyni O, Tidjani M, Sarr A, 2004. Gestion de la diversité en milieu paysan: influence de facteurs anthropiques et des flux de gènes sur la variabilité génétique des formes cultivées et spontanées du mil (Pennisetum glaucum ssp. glaucum) dans deux localités du Niger, Actes du $4 \mathrm{e}$ colloque national. Le patrimoine génétique: la diversité et la ressource. La Châtre, 14-16 octobre 2002. Bureau des ressources génétiques 2004 . 